\title{
DIVIDEND POLICY, CORPORATE GOVERNANCE AND EARNINGS QUALITY: A CASE OF NON-FINANCIAL LISTED FIRMS OF PAKISTAN Tehmina Afzal ${ }^{1 *}$, Atif Atique Siddiqui ${ }^{2}$, Shiraz Khan ${ }^{3}$, Muhammad Kamran Khan ${ }^{4}$, Nader Huseen ${ }^{5}$ \\ $1^{*, 2,3,4,5}$ Department of Management Sciences, The University of Haripur, Pakistan. \\ Email: ${ }^{1 *}$ tehminafza101@ @mail.com, ${ }^{2}$ atif.atique@ uoh.edu.pk, ${ }^{3}$ shirazkhan@uoh.edu.pk, ${ }^{4}$ mkamran.khan@uoh.edu.pk, 5 m.nader99g@gmail.com
}

Article History: Received on $11^{\text {th }}$ May 2021, Revised on $18^{\text {th }}$ May 2021, Published on $24^{\text {th }}$ May 2021

\begin{abstract}
Purpose of the study: This research empirically examined the impact of the dividend policy and corporate governance attributes (board size, board meetings, audit quality, nomination committee, board independence, remuneration committee, and CEO duality) on earnings quality (EQ) of the firms in Pakistan.

Methodology: The study used secondary data of 148 non-financial listed companies of the Pakistan Stock Exchange (PSX) with 1450 firm-year observations over 10 years from 2010 to 2019. Earning quality was assessed by the earnings management, while the values of the discretionary accruals were used to measure earnings management by employing the Modified jones model (1995). Panel regression analysis examined the impact of independent variables (dividend policy \& characteristics of $\mathrm{CG}$ ) on the dependent variable (EQ).

Main Findings: Results revealed that the dividend policy showed no significant impact on earnings quality. Also, the results indicated that the audit quality and remuneration committee have a significant negative impact on earning management and a positive impact on earning quality. However, the results illustrate that the large board size, board meetings, CEO duality, firm size, and leverage have a positive influence on earnings management and a negative impact on earnings quality. Overall the study found that the corporate governance characteristics, firm size, and leverage influence the earnings quality of the firms in Pakistan.

Applications of this study: The empirical results of the study will help to improve the understanding of dividend policy \& corporate governance attributes in relationship with the EQ. Second, as dividend is considered one of the most important factors influencing investment decisions, so this endeavour will clarify to the investors and regulators that whether dividend will predict the quality of earnings in Pakistani firms.
\end{abstract}

Novelty/Originality of this study: This study extends the literature of earnings quality that is very thin in Pakistan.

Keywords: Earnings Quality, Earnings Management, Discretionary Accruals, Pakistan, Dividend Policy, Corporate Governance Characteristics.

\section{INTRODUCTION}

A large number of corporate scandals and failures (like Enron, WorldCom, Xerox) around the world eroded the trust and the confidence of the investor in financial statements (FS). This has raised questions on the effectiveness and reliability of the financial reports (Fodio, Ibikunle, \& Oba, 2013). Goncharov (2005) argued that the main reason behind these scandals was earnings manipulation. And this, in turn, made the reported earnings quality worse, and the investors lost their confidence in financial reports, specifically in the reported earnings (González \& García-Meca, 2014). Earnings manipulation has been considered to be the most common method used by the management of the firms to mislead the users (stakeholders) of the financial reports by reporting idealistic numbers in the reported earnings (Miko \& Kamardin, 2015). There have been several reasons for doing the earnings manipulation and presenting false information about the earnings quality. Most common are expectations for the higher returns on the investment by the firms' shareholders, maintain the good condition of the firms in the market, attract more investors, and satisfy the demands of the company's management (Hassan \& Farouk, 2014).

So the earning figures and their quality have great importance in the business field as it becomes the basis of investment decisions. The capital markets set security prices, market efficiency is also based upon the given information, and if that information is misrepresented, then it affects all economic decisions (Epps \& Ismail, 2009). Considering the importance of earnings quality, researchers have argued that earning quality acts as the backbone of the firm, so every firm wants to attain the maximum level of quality in its earnings. Also, the firm's better earnings quality is a sign of longer survival of the firm (Sae-Lima \& Jermsittiparsertb, 2019). According to Azzoz, Abdel, and Khamees (2016), earnings quality (EQ) \& earnings management(EM) are like the two sides of the same coin, if the earnings management (EM) is more or high then the earnings quality (EQ) is less or low and vice versa, hence the earnings management depicts the quality of earnings of any firm. Earnings quality is the ability that enables the users to predict the earnings of the firms. On the basis of that prediction, the earnings have good quality when the past earnings of the firm are associated with the future earnings while earnings are of low quality when past earnings are unrelated to future earning (Mikhai et al., 2003). 
Fraudulent financial reporting impairs the credibility and the effectiveness of the financial statements, thus distorting the earnings quality. Hence earnings quality becomes a debatable topic and also a dilemma for the users of financial reports, and they want to know the factors that influence the earnings quality. Ismail, Kamarudin, and Sarman (2015) said that high and good quality of earnings is required for the purpose of investment and financing decisions. Therefore the researchers started conducting studies on the factors that convey information about the earnings quality which was distorted by the earnings manipulation. So in the developed economies (Hanlon, Myers, \& Shevlin, 2007; Skinner \& Soltes, 2011; Tong \& Miao, 2011; Asiri, 2014; Sirait \& Siregar, 2014; Deng, Li, \& Liao, 2017) found that there exist the association between the dividend and the earning quality because dividend payment decreases the availability of the FCF to the managers, in turn, reduces the agency problem and increases the EQ. Another argument in favour of this relation is that paying a dividend is considered as the sign of firms sound earnings, stable cash flows, and good financial performance (Deng et al., 2017). All these researches were performed in developed economies of the world.

Furthermore, (Epps \& Ismail, 2009; Waweru \& Riro, 2013; González \& García-Meca, 2014; Hassan \& Farouk, 2014; Waweru \& Prot, 2018) also found an association between CG and the EQ. These studies argued that the corporate failures around the world were due to earnings manipulation, and it happened in the companies that had weaker corporate governance mechanism, so the management, in turn, can easily mislead the investors by presenting the manipulated earning and the false earning quality (Epps \& Ismail, 2009). So from the above-mentioned facts, it is cleared that corporate governance characteristics have an association with earning manipulation and influence the earnings quality of the firms.

Moreover, there is varying evidence in research regarding the association between dividend payments, corporate governance, and earning quality (Skinner \& Soltes, 2011; He, Ng, Zaiats, \& Zhang, 2017) that found the positive impact of dividend payment on firms earning quality. While Grullon, Michaely, Benartzi, and Thaler (2005) stated that dividend payment does not present any information related to the earnings. Similarly (Fodio et al., 2013) indicated the mixed results (i.e. positive, negative, or no link) between the EQ and the CG characteristics.

So these contradictory views create a need to study all such factors in detail. Also, the prior studies were mainly conducted in the developed economies, but in the context of Pakistan, where political and economic systems are unstable, this area of research is yet to be explored. Hence the decision-makers are at risk while trying to make decisions relevant to the earnings quality of the firms and want to know all those factors that relate to the earning quality of the firms in Pakistan.

\section{Significance of the study}

Moreover, this study is significant in various ways. First, the empirical results of the study will help to improve the understanding of dividend policy \& corporate governance attributes in relationship with the EQ. Second, as dividend is considered as one of the most important factors influencing investment decisions (Wibowo, 2019) so from this endeavour, will clarify to the investors and regulators that whether a dividend will predict the quality of earnings in Pakistani firms. Third, this study is to be helpful for all the concerned parties like investors, creditors, regulators, a financial analyst in taking the necessary precautions when interpreting information from financial statements because these parties care about earnings quality, and this study minutely discusses the relationship of the earnings quality with important characteristics of the firms. Fourth, this study will give shareholders more understanding so they can monitor the actions of the managers of the firms and, in turn, increases the control over their investment. Fifth, this study extends the literature of earnings quality that is very thin in Pakistan.

\section{Objectives of the study}

Following are the objectives of the current research.

1. To discuss the findings of the studies that analyzed the impact of dividend payments on the earnings quality.

2. To explain the association between corporate governance characteristics and earnings quality.

The remaining structure of this study is as follows. Section 2 presents the underlying theories and reviews the relevant prior researches done by different researchers, hypothesis development \& the theoretical model. Section 3 outlines the methodology. Section 4 describes the empirical results \& the discussion. Section 5 reports the conclusion \& recommendations.

\section{LITERATURE REVIEW}

The topic of dividend policy, corporate governance, and earnings quality is of great importance in the business field. Several theories provide a reasonable basis for the association, and also, many types of research have been conducted to explore the relationship among them and found contradictory results. So the literature of this study is divided into two categories; firstly, it discusses the findings of the studies that analyzed the impact of dividend payments on the earnings quality. At the same 
time, the second category explained the association between corporate governance characteristics and earnings quality. Before reviewing the literature, the underlying theories of the study are explained in the first instance.

\section{The theoretical framework of the current study}

This study based on two main theories that will provide a sound basis for the explanation on the linkage between the dividend policy \& the earning quality as well as on the corporate governance and the earning quality.

\section{Signalling Theory}

Signalling theory is based on the information asymmetry that mainly happens between the managers and the outside shareholders in the market. As the management pay dividend that conveys the signals about the earnings of the corporations (Bali, 2003). Also, Sirait and Siregar (2014) supported the view that the corporations that pay dividend have higher earning quality as compared to the others. Also, some studies argued that the dividend reveals the signal about the future earnings of the firm (Hanlon, Myers, \& Shevlin, 2007). At the same time, some argued that dividend does not send any signal to the market about the earnings quality (Grullon et al., 2005).

\section{Agency Theory}

Considering the perspective of agency theory in the context of dividend, the firms that pay higher dividend make the availability of FCF less for the managers, and so the managers couldn't exploit the resources of the companies for personal use (Pinkowitz, Stulz, \& Williamson, 2006). So, in turn, the dividend payment reduces the agency problems.

While in perspective of corporate governance: As the agency problems mainly arise when a conflict of interest exists between managers and owners. So in consequences, the managers misrepresent the reported earnings for their interest. Therefore when the agency problem does not exist, then the quality of earnings will not be an issue because the managers have no personal interest to misrepresents the earnings (Fodio et al., 2013).

Although on the basis of the above arguments, the theories provide a reasonable explanation on the association between the dividend, corporate governance, and earnings quality but the results for this association may be changed according to the environment.

\section{Dividend Policy and Earnings Quality}

Many prior empirical kinds of research have been conducted to find the association between the DP and EQ. Like in Indonesia the Wibowo (2019) found a negative association between dividend payment \& discretionary accruals. And argue that the firms that pay dividend have better earning quality as compared to the non-dividend paying firms because dividendpaying firms have sustainable earnings, so they don't manipulate the earnings. Ham, Kaplan, and Leary (2019), in their research, examined whether the dividend conveys information about the future earning of firms in the US \& found that the dividend changes predicted the unexpected changes in earning quality of corporations, and it contains information related to the earnings of the firms. He et al. (2017) conducted research on the association between dividend payments and earnings management across different countries. The research found that the dividend payment negatively related to earning management and have a positive relationship with earning quality. Also, the negative association is stronger in those countries in which the investor protection is weak, so that they want to get access to external financing by building a strong reputation in the market. In China, Deng et al. (2017) found that the firms that pay dividend have more persistence earning, higher accrual quality, and better-earning information, which in turn make the quality of earnings high. Asiri (2014) found that the dividend payment gives positive signals to the market about the sustained cash flow of the firms and the future earnings. Also, the stock values of dividend-increasing firms become higher than the low dividend-paying firms. Sirait and Siregar (2014) indicated that except for dividend size all other measures of dividend that was paying status, changes in the dividend \& the persistence of the dividend significantly related to the earning quality measures. And suggested that firms paying dividend have strong cash basis and it is the signal that they have the good financial condition. Skinner and Soltes (2011) examined whether the dividend provides information about the firms quality of earnings. Research showed that the corporations that pay dividends have more persistent earning than the firms that were non-payers, and also, persistency is higher for the organizations that pay larger dividends. Also, the firms that pay dividend, the relationship between their current earnings and future earning is stronger. Tong and Miao (2011) also found positive association.

While Grullon et al. (2005) found that the dividend changes contained no information related to the changes in future earnings. Moreover, the dividend changes negatively related to the changes in future profitability that were measured by the return on asset. Also, Mousa and Desoky (2019) indicated that the dividend payment doesn't influence the earnings quality of the Egyptian firms. So it is argued that the literature on the association between the DP and EQ provides mixed results. Hence the following hypothesis is formulated based on the literature:

$\boldsymbol{H}_{1}:$ There is a significant impact of dividend payments on the earnings quality of non-financial listed firms of Pakistan. 


\section{Corporate Governance Characteristics and Earnings Quality}

\section{Board size and earnings quality}

Board size refers to the total number of directors on the board. So the researchers' tries to find whether the larger board is a symbol of better-earning quality or the smaller board. Like (González \& García-Meca, 2014; Saleem et al., 2016) found that the larger board is less efficient in monitoring the management activities and hence decreasing the EQ. While (Houqe et al., 2011; Fodio et al., 2013; Jessica, 2020) found a significant positive influence of BS on EQ and favours the larger board for less earning manipulation and good EQ. However (Khafid \& Arief, 2017; Waweru \& Prot, 2018; Mousa \& Desoky, 2019) showed no association between the BS and EQ. Hence the literature has varying results, so based on such association, the following hypothesis is proposed:

\section{$\boldsymbol{H}_{2}$ : There is a significant impact of board size on the earnings quality of non-financial listed firms of Pakistan.}

\section{Board independence and earnings quality}

Independent members don't have any major shares in the company; or in other words, independent board members have no interest in the company except the specific fee. So the researches of (Fodio et al., 2013; González \& García-Meca, 2014; Saleem et al., 2016; Khafid \& Arief, 2017) indicated that the independent board members have more expertise and performs the monitoring activities more efficiently and can detect the earnings manipulation and increases EQ. While (Hashim \& Devi, 2008; Azzoz et al., 2016; Waweru \& Prot, 2018) found that the independent directors can't identify the manipulation because they are not involved in daily activities and decisions of business so they don't have any influence on EQ. Hence the following hypothesis is formulated:

$\boldsymbol{H}_{3}$ : There is a significant impact of board independence on earnings quality of non-financial listed firms of Pakistan.

\section{Board meetings and earnings quality}

The board meeting is also the attribute of the CG that refers to the total number of meetings of the BOD of the company held during the fiscal year of the specific company. So the studies of (González \& García-Meca, 2014; Azzoz et al., 2016; $\underline{\text { Saleem }}$ et al., 2016) indicated that with more frequent board meetings, the earning quality is high because the members can identify the manipulation in the discretionary accruals and reduces the manipulation. However, Waweru and Prot (2018) found no influence of board meetings on earnings quality. Therefore the following hypothesis is proposed:

$\boldsymbol{H}_{4}$ : There is a significant impact of board meetings on the earnings quality of non-financial listed firms of Pakistan.

\section{CEO duality and earnings quality}

CEO duality occurs when CEO also occupies the position of the chairman of the board. So the researchers also found the association between the CEO duality and the EQ like (Hashim \& Devi, 2008; Epps \& Ismail, 2009) found that the firms having CEO duality have more EM and less EQ because the CEO wants to present good financial performance in front of shareholders, so he manipulates the earnings by using the discretionary accruals and in turn decreases earnings quality. While (Azzoz et al., 2016), in contrast, found no effect of CEO duality on EQ. Hence the proposed hypothesis is:

$\boldsymbol{H}_{5}$ : There is a significant relationship between CEO duality \& earnings quality of non-financial listed firms of Pakistan.

\section{Audit quality (big 4) and earnings quality}

Audit quality refers to the examination of the company's financial reporting by the high-quality auditors' teams. Therefore (Epps \& Ismail, 2009; Parte-Esteban \& García, 2014; Waweru \& Prot, 2018; Mousa \& Desoky, 2019; Sae-Lima \& Jermsittiparsertb, 2019; Jessica, 2020) argued that the firms audited by Big 4 have good EQ as compared to the firms audited by non-Big4 because of more skills, knowledge and financial expertise of the Big 4 . So they can easily detect the earnings management and can mitigate the earning manipulation by properly analyzing the activities of the management and its financial accounts and thereby enhance the earning quality. Sof management, in turn, increases the earnings quality. While (Khafid \& Arief, 2017) found no difference between the EQ of the firms audited by Big4 \& non-Big4. Hence the literature has contradictory results; therefore, the following hypothesis is formulated:

$\boldsymbol{H}_{6}:$ There is a significant impact of audit quality on earnings quality of non-financial listed firms of Pakistan.

\section{Nomination committee and earnings quality}

$\mathrm{NC}$ is the part of corporate governance attributes that evaluates the firm's BOD. So the study of Osma and Noguer (2007) found that the firms having nomination committee have good earnings quality because they selected well-skilled people who can reduce the earning manipulation activities and increase the earnings quality. So the following hypothesis is proposed: 
$\boldsymbol{H}_{7}$ : There is a significant impact of the nomination committee on the earnings quality of non-financial listed firms of Pakistan.

\section{Remuneration committee and earnings quality}

The work of Epps and Ismail (2009) found that the presence of a remuneration committee decreases the earning manipulation and increases the earnings quality. Because the committee fixes the compensation in accordance with the policies, and no one can manipulate the earnings for personal benefits. Hence the literature provides the association, so the following hypothesis is formulated:

\section{$\boldsymbol{H}_{8}$ : There is a significant impact of remuneration committee on earnings quality of non-financial listed firms of Pakistan.}

\section{Control Variables}

\section{Firm size and earnings quality}

The literature revealed that many researchers used firm size as control variables because they found it to have an association with earnings quality. Like ( $\mathrm{He}$ et al., 2017; Jessica, 2020) found that firm size has a positive association with earning management and a negative association with earning quality which indicated that the larger firms do more earning management because they want to present a good financial position of the firms in the market and turn have fewer earnings quality. While (Fodio et al., 2013; Parte-Esteban \& García, 2014) found that firm size harms earnings management which revealed that the larger firms do less earning management because they face more scrutiny from the market, so have higher earnings quality. But some studies found no association between the firm size and earning quality (Mousa \& Desoky, 2019). As the firm size and earnings quality have contradictory results in different economies. So this study used the firm size as a control variable and tried to find whether the firm size has any influence on the earnings quality of firms in Pakistan. Hence the following hypothesis is formulated based on the literature:

\section{$\boldsymbol{H}_{9}$ : There is a significant impact of firm size on the earnings quality of non-financial listed firms of Pakistan.}

\section{Leverage and Earnings Quality}

Leverage, also used as control variables in prior researches, has contradictory results. As (Waweru \& Prot, 2018; González \& García-Meca, 2014) found that the firm leverage positively related with the earnings management and indicated that the highly levered firms do more earning manipulation because they want to get the relaxation on the debt covenants and, in turn, decreases the earnings quality. While some studies like (Hassan \& Farouk, 2014; Jessica, 2020) found a negative association between earning management and leverage. Hence they supported the view that the highly levered firm faces more scrutiny from the creditors, so they do less manipulation and, in turn, have higher earning quality. Some researcher also found that leverage and earning quality has no relationship. As from the discussion, it is indicated that the leverage and earning quality has varying results. Therefore this study also used leverage as a control variable and finds the impact of firm leverage on earning quality of firms in Pakistan. So the following hypothesis is proposed:

\section{$\boldsymbol{H}_{10}:$ There is a significant impact of leverage on earnings quality of non-financial listed firms of Pakistan.}

The discussion above in the literature review on the association of dividend policy, corporate governance characteristics, firm size, and leverage with the earnings quality revealed mixed results. Some studies supported the positive relationship between DP, CG, and EQ (Sirait \& Siregar, 2014; Younis et al., 2016; Waweru \& Prot, 2018; Wibowo, 2019) and argued that the firms paying a dividend and good corporate governance characteristics have higher earnings quality and supported the view that such firms have more control on the management and can detect the earning manipulation hence increasing the level of earning quality by decreasing the earning manipulation. Some studies also supported the negative relationship. However, some found no relationship between the DP, CG, and EQ (Grullon et al., 2005; Khafid \& Arief, 2017; Mousa \& Desoky, 2019).

\section{METHODOLOGY}

To analyze the influence of dividend policy and CG characteristics on EQ, data for relevant variables are collected from the State Bank of Pakistan (SBP), the website of the Pakistan Stock Exchange (PSX), and annual reports of companies. Furthermore, data for dividend policy (stock prices) is taken from the website of investing.com. This research uses panel data for 10 years from 2010 to 2019. Panel data methodology is employed in this research because the panel data can easily estimate and also identify the effects that are undetectable in time series or cross-section data (Younis et al., 2016). The initial sample of the study was consist of 380 companies from all the non-financial sectors of PSX, while in the data selection process, most of the firms were excluded because of the unavailability of the required data like their annuals reports and stock prices were missing. Also, some firms are removed in the outlier's process. Also, firms in the financial sector have been excluded because accruals of firms in the financial sector are different from the companies in the non-financial sector, so the accruals of financial firms cannot be comparable with the accruals of the firms in other sectors, and also financial 
sector has different statutory requirements (Hashim \& Devi, 2008; Tong \& Miao, 2011). So the final sample consists of 145 companies with 1450 firm-year observation.

\section{Variables of the Study}

\section{Estimation of Dependent Variable}

The dependent variable of the current study is earning quality (EQ). EQ has been assessed by earning management, and in turn, the earning management is estimated by the most widely used proxy, i.e. discretionary accruals. By reviewing the literature, it is cleared that the absolute value of discretionary accruals (DAC) are used to measure earning management and earning quality (Hashim \& Devi, 2008; Waweru \& Prot, 2018; Mousa \& Desoky, 2019). A number of methods have been used to calculate the DAC, but the Modified Jones model (Dechow, Sloan, \& Sweeney, 1995) is the most common and powerful method to measure the discretionary accruals because it used cross-sectional regression, which removes the survivorship bias that arises in particular time-series data (Azzoz et al., 2016). Also, the modified jones model eliminates the chances of error that the Jones (1991) model carries during the estimation of discretionary accruals when the discretion is applied over revenues or sales (Dechow et al., 1995). Hence the Dechow et al. (1995) make amendments in the Jones model by adjusting revenues changes with the account receivables changes, so the management couldn't boost the current period earnings by the early recognition of the revenues.

So here, in current research, the Modified Jones model (1995) is used for the calculation of discretionary accruals. Firstly, total accruals (TAC) is calculated by using the cash flow approach as it is argued by the researcher that this approach is better than the balance sheet approach to measuring the accruals because it has less measurement error (Hribar \& Collins, 2002). In this approach, the TAC is calculated by taking the difference between the earnings and the cash flow from operation.

$T A C_{i t}=$ Earnings $_{i t}-C F O_{i t}$

So by putting the values of earnings and cash flow from operations in the above equation no 1 , the value of the total accruals is calculated. Then the modified jones model (1995) is applied to regressed total accruals with its specific components and the residuals. The formula is as followed;

$\frac{T A C_{i t}}{T_{A S S_{i t-1}}}=a\left(\frac{1}{T_{A S S_{i t-1}}}\right)+b \frac{(\triangle R E V-\triangle R E C)}{T_{A S S_{i t}-1}}+c \frac{P P E}{T_{A S S_{i t-1}}}+\epsilon_{i t}$

In above equation no 2; TAC $C_{i t}$ is total accruals of the firm i in year $\mathrm{t}, T A S S_{i t-1}$ is the lag of total assets, $\triangle R E V_{i t}$ is the revenues for the firm $\mathrm{i}$ in year $\mathrm{t}$ minus the rev in year $\mathrm{t}-1, \triangle R E C_{i t}$ is receivable for firm $\mathrm{i}$ in year $\mathrm{t}$ minus the receivables for firm $\mathrm{i}$ in the year $\mathrm{t}-1, P P E_{i t}$ is the value of property, plant, and equipment. After putting the values of all the components in the above equation no (2), the regression is run to calculate the values of regression coefficients $(a+b+c)$. After the regression, the normal accrual (NAC) is calculated by using the amounts of the regression coefficients, i.e. $a+b+c$. Hence the calculated value of normal accruals is then subtracted from the value of total accruals to get the value of discretionary accruals, which is our dependent variable. So to calculate the values of discretionary accruals, equation no 3 is used that is given below:

$D A C_{i t}=T A C_{i t}-N A C_{i t}$

So the earnings management measured the earning quality of the firms, and the level of earning management is assessed by the value of the discretionary accruals. Therefore the absolute values of discretionary accruals are used as a proxy to measure earnings quality.

\section{Estimation of Independent Variables}

Independent variables of the current study are dividend payment, board independence, CEO duality, the board size, audit quality, board meetings, nomination committee, and remuneration committee. So in this study, dividend policy is measured by using the formula; dividend per share/stock prices (Deng et al., 2017). Board size is measured by the total number of directors on the firm's board (Houqe et al., 2011; Chaharsoughi \& Rahman, 2013; Jessica, 2020). Board independence is assessed by the number of independent directors in the board divided by a total number of board members (González \& García-Meca, 2014). CEO duality is measured by using a dummy variable, i.e. if the chairman is also the CEO of the company, then used the dummy variable 1, and if they are separate, then 0 (Epps \& Ismail, 2009; Saleem et al., 2016). Audit quality is also measured by the use of dummy variable, i.e. if the firm is audited by the Big 4 (Deloitte, A.F. Ferguson, EY and KPMG) audit firms then put the 1 otherwise 0 (Huguet \& Gandía, 2016; Mousa \& Desoky, 2019). The board meeting is assessed by the total number of meetings conducted by the board members during the whole year (Saleem et al., 2016). Remuneration and nomination committee is also measured by using the dummy variable, i.e. a dummy variable 1 if the committees present otherwise 0 (Osma \& Noguer, 2007; Epps \& Ismail, 2009). 


\section{Control Variables}

Consistent with the previous researches, this study used the firm size (measured by logarithm of total sales) and firm leverage (total liabilities divided by total assets) as the control variables because a review of the literature provides evidence on the association between these control variables and earnings quality. Like (Houqe et al., 2011; Waweru \& Prot, 2018).

Table 1: Detail of Variables

\begin{tabular}{|c|c|c|c|c|}
\hline Variables & Type & Symbols & Measurement & $\begin{array}{l}\text { Variables used in } \\
\text { literature }\end{array}$ \\
\hline $\begin{array}{l}\text { Earnings } \\
\text { Quality(Discretionary } \\
\text { Accruals) }\end{array}$ & Dependent & EQ(DAC) & $\begin{array}{l}\text { Measured by Modified } \\
\text { Jones Model(1995) }\end{array}$ & $\begin{array}{l}\text { (Waweru \& Prot, 2018; } \\
\text { Mousa \& Desoky, 2019) }\end{array}$ \\
\hline Dividend Policy & Independent & DP & $\begin{array}{lll}\begin{array}{l}\text { Dividend per share/ } \\
\text { stock prices }\end{array} & \\
\end{array}$ & (Deng et al., 2017) \\
\hline Board Size & Independent & BS & $\begin{array}{l}\text { Total number of } \\
\text { members in firms board }\end{array}$ & $\begin{array}{l}\text { Hashim \& Devi, 2008; } \\
\text { Mousa \& Desoky, 2019) }\end{array}$ \\
\hline Board Independence & Independent & BI & $\begin{array}{l}\text { Number of independent } \\
\text { directors in board/ total } \\
\text { board members }\end{array}$ & $\begin{array}{l}\text { (Hashim \& Devi, 2008; } \\
\text { Mousa \& Desoky, 2019; } \\
\text { Jessica, 2020) }\end{array}$ \\
\hline Board Meetings & Independent & $\mathrm{BM}$ & $\begin{array}{l}\text { If duality exists then the } \\
\text { dummy variable contains } \\
\text { the value } 1 \text {, otherwise } 0 .\end{array}$ & (Saleem et al., 2016) \\
\hline CEO Duality & Independent & CEOD & $\begin{array}{l}\text { Dummy variable } 1 \text { if } \\
\text { firm is audited by Big4, } \\
\text { otherwise } 0 \text {. }\end{array}$ & $\begin{array}{l}\text { (Epps \& Ismail, 2009; } \\
\text { González \& García-Meca, } \\
\text { 2014; Jessica, 2020) }\end{array}$ \\
\hline Audit Quality & Independent & AQ & $\begin{array}{l}\text { Total number of board } \\
\text { meetings conducted } \\
\text { during fiscal year. }\end{array}$ & $\begin{array}{l}\text { (Epps \& Ismail, 2009; } \\
\text { González \& García-Meca, } \\
\text { 2014; Jessica, 2020) }\end{array}$ \\
\hline Nomination Committee & Independent & $\mathrm{NC}$ & $\begin{array}{l}\text { If nomination committee } \\
\text { present then dummy } \\
\text { variable } 1 \text {, otherwise } 0 .\end{array}$ & $\begin{array}{l}\text { (Epps \& Ismail, 2009; } \\
\text { Osma \& Noguer, 2007). }\end{array}$ \\
\hline $\begin{array}{l}\text { Remuneration } \\
\text { Committee }\end{array}$ & Independent & $\mathrm{RC}$ & $\begin{array}{l}\text { Dummy variable } 1 \text { if } \\
\text { remuneration committee } \\
\text { present, otherwise } 0 .\end{array}$ & $\begin{array}{l}\text { (Epps \& Ismail, 2009; } \\
\text { Osma \& Noguer, 2007). }\end{array}$ \\
\hline Leverage & Control & LEV & $\begin{array}{l}\text { Total liabilities to total } \\
\text { asset }\end{array}$ & (Osma \& Noguer, 2007) \\
\hline Firm Size & Control & FS & Logarithm of sales & (Waweru \& Prot, 2018) \\
\hline
\end{tabular}

Therefore, to test the impact of dividend policy and corporate governance characteristics on earnings quality the estimated model is as follow;

$D A C_{i t}=\beta_{o}+\beta_{1} D P_{i t}+\beta_{2} B S_{i t}+\beta_{3} B I_{i t}+\beta_{4} B M_{i t}+\beta_{5} D_{1}+\beta_{6} D_{2}+\beta_{7} D_{3}+\beta_{8} D_{4}+\beta_{9} F S_{i t}+\beta_{10} L E V_{i t}+\epsilon_{i t}$

\section{Estimation Techniques}

Descriptive statistics are used in this study. Mean, maximum, minimum, and standard deviation values of the descriptive statistics are used. Correlation analysis is used to check the relationship between the variables. While multiple panel regression model is used to check the impact of the independent variable on the dependent variable. For the selection of model, the Hausman test is applied, which defines whether a fixed-effect model or random effect model is used. Dummy variable analysis is also used in the research. To check the problem of multicollinearity between the explanatory variables, the Variance Inflation Factor (VIF) values are analyzed, and that values are less than 10, which indicated that no multicollinearity exists between the variables as shown in table (2) below. However, the heteroscedasticity issue is checked by using the Breusch-Pagan test. Hence the significant value of chi-square indicates heteroscedasticity problem. To check autocorrelation, the value of Durbin Watson is analyzed. The range of no autocorrelation of Durbin Watson is from 1.5 to 2.5. Eviews and Stata software is used to analyze the data.

\section{Multicollinearity}

Table 2 depicts the VIF values for checking multicollinearity. 
Table 2: Multicollinearity Test Statistics

\begin{tabular}{ll}
\hline Variables & VIF Value \\
\hline DP & 1.3061 \\
\hline BS & 2.0434 \\
\hline BI & 1.0733 \\
\hline BM & 2.0230 \\
\hline CEOD & 1.2327 \\
\hline AQ & 1.0681 \\
\hline NC & 1.4512 \\
\hline LC & 1.4482 \\
\hline FE & 2.1403 \\
\hline
\end{tabular}

\section{Hausman Test}

However, for the selection of the model, the Hausman test is applied, which selects either the fixed effect or random effect model is suitable for analysis. So the Hausman test is applied, and results indicated that the fixed effect model is suitable for the current study because of the significant p-value of Hausman tests that is shown in table 3 .

Table 3: Hausman Test Statistics

\section{Breusch-Pagan-Godfrey Test}

\begin{tabular}{lll}
\hline \multicolumn{3}{l}{ Hausman Specification Test } \\
\hline & Chi-square test value & P-value \\
\hline Model I & 37.977 & 0.0001 \\
\hline
\end{tabular}

Moreover, to check the heteroscedasticity issue Breusch-Pagan-Godfrey test is applied to sample or data. The significant value of chi-square indicates the problem of heteroscedasticity in data. Hence white correction for standard error is applied to resolve the issue of heteroscedasticity, and it is shown in table 4.

Table 4: Breusch-Pagan-Godfrey test

\begin{tabular}{lll}
\hline \multicolumn{3}{l}{ Breusch-Pagan test statistics } \\
\hline & Obs* R-squared & Prob. Chi-square \\
\hline Model I & 27.367 & 0.0023 \\
\hline
\end{tabular}

\section{RESULTS AND DISCUSSION}

\section{Descriptive Statistics}

The descriptive statistics of all the variables, i.e. dependent, independent, and control variables of the current study, are shown in table 5. At the same time, the descriptive statistics of dichotomous variables that are also the explanatory variables in this study are presented in table 5.1. The descriptive statistics represents the mean, maximum and minimum values along with the standard deviation values. So the table depicted that the magnitude of the mean value of the discretionary accruals that is proxy of earning management is 0.065 , whereas the standard deviation is 0.16 and the minimum value is -0.245 , along with the maximum value of 0.762 . The dividend policy has a mean value of 0.048 with a standard deviation value of 0.104 . The maximum and the minimum value of the dividend policy are 2.25 and 0.0012 correspondingly. The mean board size of the sample is 7.82, along with a 1.159 standard deviation value. However, the range of maximum board size is 12 , and the minimum values are 7 . Board independence that is assessed by the \% of independent members in the board has a mean value of 0.206 along with a standard deviation value of 0.106 , while the maximum and the minimum values are 0.636 and 0.090 , respectively. The magnitude of the mean value of board meeting is 5 along with the standard deviation of 1.431 , whereas the maximum \& minimum number of the board meeting is 12 and 2. However, the firm size has a mean value of 6.679 with a standard deviation of 0.645 . The range of maximum value of firm size is 8.509 , and the minimum value is 4.99 . On the other hand, the firm leverage has the means value of 0.790 with a standard deviation value of 0.136 , while the maximum and the minimum values are 1.349 and 0.193 , respectively.

Table 5: Descriptive Statistics

\begin{tabular}{llllll}
\hline Variables & Obs & Mean & Maximum & Minimum & St.dev. \\
\hline DAC & 1450 & 0.0655 & 0.7628 & -0.2456 & 0.1687 \\
\hline
\end{tabular}




\begin{tabular}{llllll}
\hline DP & 1450 & 0.0488 & 2.2598 & 0.0012 & 0.1043 \\
\hline BS & 1450 & 7.8427 & 12.0000 & 7.0000 & 1.1598 \\
\hline BI & 1450 & 0.2062 & 0.6360 & 0.0900 & 0.1065 \\
\hline BM & 1450 & 5.0734 & 12.0000 & 2.0000 & 1.4315 \\
\hline FS & 1450 & 6.6790 & 8.5098 & 4.9983 & 0.6459 \\
\hline LEV & 1450 & 0.7902 & 1.3498 & 0.1932 & 0.1366 \\
\hline
\end{tabular}

\section{Dichotomous Variables}

Furthermore, table 5.1 demonstrates the frequency of the dichotomous variables or the dummy variables that only take the value of 0 or 1 . Statistics showed that $84.3 \%$ of the sample companies had separated the role of chairman and CEO while CEO duality exists only in $15.7 \%$ sample where the role of chairman and CEO is performed by the same person. Considering the audit quality, the frequency showed that $54.6 \%$ of the selected sample is audited by the Big4 (Deloitte, A.F. Ferguson, Ernst and Young, KPMG) while $45.4 \%$ of the sample is audited by the non Big4. The nomination committee is present in $43.1 \%$ of the sample companies, while $56.9 \%$ sample has no nomination committee. Moreover, $72.6 \%$ of the sample has the remuneration committee, while $27.4 \%$ of the sample has no remuneration committee.

Table 5.1: Dichotomous Variables

\begin{tabular}{llll}
\hline Variables & Obs & Frequency of 0 & Frequency of 1 \\
\hline CEOD & 1450 & $1223(84.3 \%)$ & $227(15.7 \%)$ \\
\hline AQ & 1450 & $658(45.4 \%)$ & $792(54.6 \%)$ \\
\hline NC & 1450 & $826(56.9 \%)$ & $624(43.1 \%)$ \\
\hline RC & 1450 & $398(27.4 \%)$ & $1052(72.6 \%)$ \\
\hline
\end{tabular}

\section{Pearson Correlation Matrix}

Table 6 illustrates the results of the Pearson correlation matrix that explain the association between different variables of the current study. So here the correlation explains the association between the discretionary accrual, which is used as the proxy for earning quality, and all the other variables, i.e. dividend policy, corporate governance characteristics (board size, board meetings, nomination committee, board independence, audit quality, CEO duality, and remuneration committee) leverage, and the firm size. The table showed that the dividend policy has a negative association with the discretionary accruals. Board size has a positive correlation with discretionary accruals. Board independence showed a positive association with the discretionary accruals. The board meetings also have a positive association with earning management. CEO duality has a positive association with the discretionary accruals, while the audit quality (Big4) is found to have a significant negative relation with the discretionary accruals. The nomination committee is positively related to DAC, while the remuneration committee has a negative association with the DAC. Firm size and leverage are significantly positively associated with DAC. Furthermore, the coefficient values of all other independent variables are low. This indicates a lack of multicollinearity issue.

Table 6: Correlation Analysis

\begin{tabular}{|c|c|c|c|c|c|c|c|c|c|c|c|}
\hline Variables & DAC & DP & BS & BI & BM & CEOD & $\mathbf{A Q}$ & $\mathrm{NC}$ & RC & FS & LEV \\
\hline DAC & 1.000 & & & & & & & & & & \\
\hline DP & -0.0056 & 1.000 & & & & & & & & & \\
\hline BS & 0.1438 & -0.0096 & 1.000 & & & & & & & & \\
\hline BI & 0.1133 & 0.0892 & -0.0902 & 1.000 & & & & & & & \\
\hline BM & 0.1273 & 0.0032 & 0.0775 & 0.1023 & 1.000 & & & & & & \\
\hline CEOD & 0.1066 & -0.0816 & 0.1982 & 0.0852 & 0.0896 & 1.000 & & & & & \\
\hline $\mathbf{A Q}$ & -0.0236 & 0.0363 & -0.0838 & -0.0168 & -0.0515 & -0.1836 & 1.000 & & & & \\
\hline $\mathrm{NC}$ & 0.1168 & -0.0771 & 0.2152 & -0.0329 & 0.0515 & 0.2118 & -0.0714 & 1.000 & & & \\
\hline RC & -0.0177 & -0.2157 & 0.0737 & -0.01867 & 0.0003 & 0.0370 & -0.0846 & 0.0917 & 1.000 & & \\
\hline FS & 0.0442 & -0.0129 & 0.1701 & 0.0167 & 0.0407 & 0.2779 & 0.0714 & 0.1772 & 0.1049 & 1.000 & \\
\hline LEV & 0.0261 & 0.0363 & -0.0497 & -0.0687 & -0.0731 & -0.1826 & 0.0662 & -0.1273 & -0.0560 & -0.0238 & 1.000 \\
\hline
\end{tabular}

Significant level: $0.01,0.05,0.1$

\section{Regression Analysis}

Regression analysis is used in this study to check the impact of independent variables on the dependent variable. Hence the panel regression is used to check the influence of dividend policy and CG characteristics on the earning quality, and all the variables are regressed by using the fixed effect regression model \& the results are given below in table 7. 


\section{Results of Fixed Effect Regression Model}

Table 7: Fixed Effect Regression Model

\begin{tabular}{llll}
\hline Variables & Coefficient & t-Statistic & Prob. \\
\hline C & 2.80105 & 7.13068 & 0.0000 \\
\hline DP & -0.04998 & -0.93188 & 0.3516 \\
\hline BS & 0.64777 & 4.18335 & 0.0000 \\
\hline BI & 0.07106 & 1.13181 & 0.2579 \\
\hline BM & 0.32231 & 2.52762 & 0.0116 \\
\hline CEOD & 0.12873 & 3.78407 & 0.0002 \\
\hline AQ & -0.11929 & -6.55820 & 0.0000 \\
\hline NC & 0.01807 & 0.39071 & 0.6961 \\
\hline RC & -0.08276 & -2.29903 & 0.0217 \\
\hline FS & 0.24316 & 3.91003 & 0.0001 \\
\hline LEV & 0.48255 & 3.17813 & 0.0015 \\
\hline Adjusted R- squared & 0.779 & Durbin Watson stat & 1.617 \\
\hline F-statistic & 34.160 & Prob (F-statistic) & 0.000 \\
\hline
\end{tabular}

Significant level: 0.01, 0.05, 0.1.

Table 7 reports the results of the impact of dividend policy, characteristics of the on EQ. So results of the regression model revealed that the $\mathrm{p}$-value of dividend policy is 0.351 , which is greater than 0.05 with a coefficient value of -0.049 . So there exists an insignificant impact of dividend policy on EM. But the direction of association is negative that is consistent with the correlation matrix, and indicated that a weak negative association exists between the DP and the earning management. These results are consistent with the study of Mousa and Desoky (2019), who also found an insignificant relationship between the firm's dividend and its earning quality. At the same time, the results are inconsistent with findings of (Skinner \& Soltes, 2011; Tong \& Miao, 2011; Sirait \& Siregar, 2014; Deng et al., 2017; Ham et al., 2019), who found the significant positive impact of DP on EQ. Hence the above-mentioned results of the current study indicated that the dividend payment does not send any signal about earning quality and the future earnings of the firms. It is consistent with the results of (Grullon et al., 2005), who argued that although the firms do earn manipulation it is not depicted from the dividend policy of the firms, and also the DP doesn't convey the information about the earnings of the firms and their quality, so the dividend doesn't send a signal about the earnings of the firms. So the $\mathrm{H}_{1}$ is rejected because there is no significant impact of DP on EQ.

While considering the characteristics of corporate governance, the p-value of the board size is 0.00 , which is significant because it is less than 0.05 and the coefficient value of 0.64 , which showed the significant positive impact of board size on discretionary accruals and also on earning manipulation while the significant negative impact on the earning quality. These are consistent with findings of (González \& García-Meca, 2014; Saleem et al., 2016; Younis et al., 2016), who argued that with larger board size, the earning management is more because of their less efficiency in monitoring the management activities and identifying the manipulation that mainly occurred in discretionary accruals and turns to earn quality decreases. Furthermore, it is indicated that the smaller board size is more effective in constraining the EM by decreasing the value of DAC. However, these results are inconsistent with (Khafid \& Arief, 2017; Waweru \& Prot, 2018; Mousa \& Desoky, 2019), who found no relationship between the board size and earning quality. Also, it is inconsistent with the results of (Fodio et al., 2013), who found a negative association between board size and earning management. So based on the above results, $\mathrm{H}_{2}$ is accepted that there exists a significant negative impact of BS on EQ.

The p-value of the board independence 0.257 is insignificant, along with the coefficient values 0.0002 , which illustrated the insignificant impact of board independence (BI) on earning quality (EQ). It is consistent with the study of (Hashim \& Devi, 2008; Azzoz et al., 2016), who found similar results and argued that the independent directors have lack of expertise, skills, and knowledge about financial reporting and also they are not involved in the decision-making process on a daily basis so they cannot detect the earning manipulation. However, it is inconsistent with the results of (Fodio et al., 2013; González \& García-Meca, 2014), who found a significant positive association between board independence (BI) and earning quality (EQ). So $\mathrm{H}_{3}$ is rejected because the BI has no significant impact on EQ.

The p-value of the board meetings is 0.01 with the coefficient value of 0.32 , which indicated the significant positive impact of board meetings on EM. It is consistent with the study of (Gulzar 2011; Waweru \& Prot, 2018), who found that the board meetings cannot detect the earning manipulation. It is inconsistent with the results of (González \& García-Meca, 2014) that indicated the significant negative influence of board meeting on EM and argued that with more frequent board meetings, the 
earning manipulation has been easily detectable and lowering values of discretionary accruals, which in turn make the earning quality high. Hence the $\mathrm{H}_{4}$ is accepted, as the BM has a significant negative impact on EQ.

The p-value of CEO duality is 0.00 with the value of the coefficient of 0.128 , which revealed the significant positive impact of CEO duality on earning manipulation while a significant negative impact on earning quality. These findings are consistent with the findings of (Hashim \& Devi, 2008; Epps \& Ismail, 2009; Gulzar, 2011), who stated that the firms having duality role have more earning manipulation and less earning quality. Because the CEO is also held responsible for the performance of the company in front of the shareholders, so he manipulates the earnings by increasing the value of discretionary accruals for personal benefits and, in turn, decreases the earning quality. However, the above results are inconsistent with the work of those who found that CEO duality has no impact on earning quality. Hence on the basis of the above-mentioned results, the $\mathrm{H}_{5}$ is accepted because CEO duality has a significant negative impact on earning quality.

The p-value of audit quality is 0.00 and is less than 0.05 , and the coefficient value is -0.11 , which indicated the significant negative impact of audit quality on earnings manipulation while the positive impact on earning quality. The results are similar to the findings of (Epps \& Ismail, 2009; Parte-Esteban \& García, 2014; Waweru \& Prot, 2018; Mousa \& Desoky, 2019; Jessica, 2020), who argued that as the firms audited by Big4, then the earning quality is high in such firms. Because the Big 4 has more financial expertise and knowledge so they can easily detect the earning manipulation and can mitigate the earning management by properly analyzing the activities of the management and its financial accounts and thereby enhance the earning quality. So the firms audited by the big 4 have higher earning quality as compared to the firms that are not audited by big4. At the same time, it is inconsistent with the work of (Huguet \& Gandía, 2016), who found that AQ has no influence on the EQ. So the $\mathrm{H}_{6}$ is accepted because the audit quality has a significant positive impact on the earning quality.

The p-value of the nomination committee is 0.69 , which is more than 0.05 , and the coefficient value is 0.018 , which showed an insignificant impact of the nomination committee on earning management. So it is inconsistent with the results of Osma and Noguer (2007), who gave the reason for a negative association that the committee selects the well-skilled and educated people who have the market experience so they can reduce the earning manipulation and increases the earning quality. However, the $\mathrm{H}_{7}$ is rejected because of the insignificant impact of the nomination committee on earning quality.

The p-value of the remuneration committee is 0.02 , which is less than 0.05 , along with the coefficient value of -0.08 and indicated the significant negative impact of the remuneration committee on earning management while the significant positive impact on earning quality. It is consistent with the study of Epps and Ismail (2009) who argued that firms having remuneration committee have a lower value of discretionary accruals and high earning quality because the committee fixes the compensation on the basis of rules of the company which in turn mitigate the conflicts and no one can manipulate the earnings for personal benefit hence the earning quality increases. From the above results, the $\mathrm{H}_{8}$ is accepted because the remuneration committee has a significant positive impact on earning quality.

So overall, the results support the agency theory perspective in the context of corporate governance. An agency problem arises when there is a conflict of interest between managers \& owners. So in consequences, the managers misrepresent the reported earnings for their personal interest. So when the company have good governance, the agency problem does not exist, and the quality of earnings will not be an issue because the managers have no personal interest to misrepresents the earnings (Fodio et al., 2013; Latif et al., 2017). Hence a good and proper governance mechanism can mitigate the earning manipulation and increase the earning quality by reducing the agency problems. Also, the firms having higher investor protection and regulations have a higher level of earnings quality (Chen \& Hung, 2021; González \& García-Meca, 2014; Maglio, Rey, Agliata, \& Lombardi, 2020).

Considering the p-value of the control variable, that is, firm size shows that it is 0.00 , which is less than 0.05 with the coefficient value of 0.24 and revealed the significant positive impact of firm size on discretionary accruals that depicts the earning manipulation. And found a significant negative impact of FS on the earning quality. This is consistent with the work of (Epps \& Ismail, 2009; Hassan \& Farouk, 2014; Jessica, 2020) and argued that the larger firms increases the value of discretionary accruals and do more earning manipulation because they want to present good financial condition of the firm in the market and wants to attract more investor so in doing so, they manipulate the earnings by making changes in the discretionary accruals and in return the earning quality is effected. While it is inconsistent with the work of some researchers who found a negative relationship between the firm size and earning management (Fodio et al., 2013). Hence the $\mathrm{H}_{9}$ is accepted because the firm size has a significant negative impact on earnings quality

The other control variable leverage also has a significant p-value of 0.00 with a coefficient value of 0.48 . And results revealed that there exists a significant positive impact of leverage on earning manipulation while a significant negative impact on earnings quality. It is consistent with the research of (Waweru \& Prot, 2018;) who found that the highly levered firms do more manipulation of the earnings because they have pressure from the creditors, and they want to get relaxation on their debt covenants, so they make changes in the discretionary accruals hence manipulating the earning and decreases the quality of earnings. However, it is inconsistent with the work of (Hassan \& Farouk, 2014; Parte-Esteban \& García, 2014; 
Waweru \& Prot, 2018), who found a negative relation between EM and leverage. So the $\mathrm{H}_{10}$ is accepted because the leverage has a significant positive impact on earning management while the significant negative impact on earnings quality.

Furthermore, the adjusted R-squared of this model is $77 \%$ which indicated that the $77 \%$ variation in earning quality is explained by dividend policy, CEO duality, the board size, audit quality, board independence, nomination committee, board meetings, remuneration committee, firm size, and leverage. The Durbin-Watson value is 1.61 , which shows no problem of autocorrelation in this model. The F-value of this model is $34 \%$ which suggested that the overall model is significant.

\section{CONCLUSION}

This study examined the impact of dividend policy and corporate governance on the earnings quality of 145 non-financial listed firms of Pakistan. The results suggested that the dividend policy does not predict the earnings quality of the firms. Also, it was found that the smaller size of the board is the indication of fewer earnings manipulation and good earnings quality. Furthermore, the existence of CEO duality is a sign of low earnings quality and greater earnings manipulation. At the same time, the firms audited by the Big4 have good earnings quality because of more expertise and skills. And the presence of a remuneration committee is also the indication of less earning manipulation and good earning quality. Moreover, large firm size and high leverage indicate greater earnings manipulation and thus the low earnings quality. So overall results revealed that there exist a significant impact of CG characteristics on the earnings quality of the firms in Pakistan. And all the users of financial reports, i.e. investors, creditors, analysts, regulators, can assess the earnings quality and the earning manipulation of the firms by analyzing the corporate governance characteristics, leverage, and size of the firms.

\section{LIMITATIONS AND FUTURE RESEARCH DIRECTIONS}

Although this endeavour contributes to understanding the association between dividend policy, CG characteristics, and earnings quality. But still, the results cannot be generalized in other countries having different cultures and business environments. Furthermore, this research work only considered one proxy for the measurement of dividend policy, i.e., dividend per share divided by stock prices. Future studies may be conducted by using other proxies. The sample size is also limited due to data availability constraints.

\section{RECOMMENDATIONS}

It is recommended to replicate a similar study in countries that have similar business conditions, like Pakistan. Also, the dividend policy can be measured by using many other proxies, i.e. dividend paying status, size of the dividend, changes in dividend, and dividend persistence for more robust results. It is also suggested that future studies can extend the time frame as well as the sample size for further investigation. Also, a comparative study on the association between the DP, CG, and EQ across different countries is recommended. It is also suggested that the relationship between dividend policy, CG characteristics, and earnings quality can be captured by using other proxies of EQ, i.e. earning persistence, earnings smoothness, earnings timeliness, and earnings response coefficients.

\section{ACKNOWLEDGEMENT}

We would like to thank all the independent reviewers of HSSR who conducted a feasibility study of our research work.

\section{AUTHORS CONTRIBUTION}

Tehmina Afzal, Atif Atique Siddiqui, wrote the research paper and designed this paper's organization; Shiraz Khan, Muhammad Kamran Khan, Nader Huseen performed the statistical analysis, interpretations, and technical parts. Thus, all authors contributed significantly to this research.

\section{REFERENCES}

1. Asiri, B. K. (2014). Dividend announcement: Is it a good news to the Bahrain Bourse. International Journal of Economics and Finance, 6(12), 223-248. https://doi.org/10.5539/ijef.v6n12p228

2. Azzoz, M., Abdel, A. R., \& Khamees, B. A. (2016). The Impact of Corporate Governance Characteristics on Earnings Quality and Earnings Management: Evidence from Jordan. Jordan journal of business administration, 12(1), 187-207. https://doi.org/10.12816/0030061

3. Bali, R. (2003). An empirical analysis of stock returns around dividend changes. Applied Economics, 35(1), 51-61. https://doi.org/10.1080/0003684020158930

4. Chen, R. C., \& Hung, S. W. (2021). Exploring the impact of corporate social responsibility on real earning management and discretionary accruals. Corporate Social Responsibility and Environmental Management, 28(1), 333-351. https://doi.org/10.1002/csr.2052

5. Dechow, P. M., Sloan, R. G., \& Sweeney, A. P. (1995). Detecting earnings management. Accounting Review, 70(2), 193-225. 
6. Deng, L., Li, S., \& Liao, M. (2017). Dividends and earnings quality: Evidence from China. International Review of Economics \& Finance, 48, 255-268. https://doi.org/10.1016/j.iref.2016.12.011

7. Epps, R. W., \& Ismail, T. H. (2009). Board of directors' governance challenges and earnings management. Journal of Accounting \& Organizational Change, 5(3), 490-536. https://doi.org/10.1108/18325910910986981

8. Fodio, M. I., Ibikunle, J., \& Oba, V. C. (2013). Corporate governance mechanisms and reported earnings quality in listed Nigerian insurance firms. International Journal of Finance and Accounting, 2(5), 279-286.

9. García-Sánchez, I. M., \& García-Meca, E. (2017). CSR engagement and earnings quality in banks. The moderating role of institutional factors. Corporate Social Responsibility and Environmental Management, 24(2), 145-158. https://doi.org/10.1002/csr.1405

10. Goncharov, I. (2005). Earnings management and its determinants: Closing gaps in empirical accounting research. Peter Lang.

11. González, J. S., \& García-Meca, E. (2014). Does corporate governance influence earnings management in Latin American markets? Journal of Business Ethics, 121(3), 419-440. https://doi.org/10.1007/s10551-013-1700-8

12. Grullon, G., Michaely, R., Benartzi, S., \& Thaler, R. H. (2005). Dividend changes do not signal changes in future profitability. The Journal of Business, 78(5), 1659-1682. https://doi.org/10.1086/431438

13. Gulzar, M. A. (2011). Corporate governance characteristics and earnings management: Empirical evidence from Chinese listed firms. International Journal of Accounting and Financial Reporting, 1(1), 133. https://doi.org/10.5296/ijafr.v1i1.854

14. Ham, C. G., Kaplan, Z. R., \& Leary, M. T. (2020). Do dividends convey information about future earnings? Journal of Financial Economics, 136(2), 547-570. https://doi.org/10.1016/j.jfineco.2019.10.006

15. Hanlon, M., Myers, J. N., \& Shevlin, T. J. (2007). Are dividends informative about future earnings? Available at SSRN 964279. https://doi.org/10.2139/ssrn.964279

16. Hashim, H. A., \& Devi, S. (2008). Board characteristics, ownership structure and earnings quality: Malaysian evidence. Research in Accounting in Emerging Economies, 8(97), 97-123. https://doi.org/10.1016/S14793563(08)08004-3

17. Hassan, S. U., \& Farouk, M. A. (2014). Firm attributes and earnings quality of listed oil and gas companies in Nigeria. Review of Contemporary Business Research, 3(1), 99-114.

18. He, W., Ng, L., Zaiats, N., \& Zhang, B. (2017). Dividend policy and earnings management across countries. Journal of Corporate Finance, 42, 267-286. https://doi.org/10.1016/j.jcorpfin.2016.11.014

19. Hribar, P., \& Collins, D. W. (2002). Errors in estimating accruals: Implications for empirical research. Journal of accounting research, 40(1), 105-134. https://doi.org/10.1111/1475-679X.00041

20. Huguet, D., \& Gandía, J. L. (2016). Audit and earnings management in Spanish SMEs. BRQ Business Research Quarterly, 19(3), 171-187. https://doi.org/10.1016/j.brq.2015.12.001

21. Ismail, W. A. W., Kamarudin, K. A., \& Sarman, S. R. (2015). The quality of earnings in Shariah-compliant companies: evidence from Malaysia. Journal of Islamic Accounting and Business Research, 6(1), 19-41. https://doi.org/10.1108/JIABR-03-2013-0005

22. Jessica, V. (2020). The Effect of firm characteristics and good corporate governance characteristics to earning management behaviors. Journal of Accounting, Finance and Auditing Studies, 6(2), 31-49. https://doi.org/10.32602/jafas.2020.009

23. Khafid, M., \& Arief, S. (2017). Managerial ownership, corporate governance and earnings quality: the role of institutional ownership as moderating variable. Pertanika Journal of Social Science and Humanities, 25(3), 241254.

24. Latif, K., Bhatti, A. A., \& Raheman, A. (2017). Earnings quality: A missing link between corporate governance and firm value. Business \& Economic Review, 9(2), 255-280. https://doi.org/10.22547/BER/9.2.11

25. Maglio, R., Rey, A., Agliata, F., \& Lombardi, R. (2020). Connecting earnings management and corporate social responsibility: A renewed perspective. Corporate Social Responsibility and Environmental Management, 27(2), 1108-1116. https://doi.org/10.1002/csr.1868

26. Mikhai et al. (2003). The effect of experience on security analyst underreaction. Journal of accounting and economics, 35(1), 101-116. https://doi.org/10.1016/S0165-4101(02)00099-X

27. Miko, N. U., \& Kamardin, H. (2015). Impact of audit committee and audit quality on preventing earnings management in the pre-and post-Nigerian corporate governance code 2011. Procedia-Social and Behavioral Sciences, 172, 651-657. https://doi.org/10.1016/j.sbspro.2015.01.415

28. Mousa, G. A., \& Desoky, A. (2019). The effect of dividend payments and firm's attributes on earnings quality: empirical evidence from Egypt. Investment management and financial innovations(16, Iss. 1), 14-29. https://doi.org/10.21511/imfi.16(1).2019.02 
29. Osma, B. G., \& Noguer, B. G. d. A. (2007). The effect of the board composition and its monitoring committees on earnings management: Evidence from Spain. Corporate Governance: An International Review, 15(6), 1413-1428. https://doi.org/10.1111/j.1467-8683.2007.00654.x

30. Pinkowitz, L., Stulz, R., \& Williamson, R. (2006). Does the contribution of corporate cash holdings and dividends to firm value depend on governance? A cross-country analysis. The journal of finance, 61(6), 2725-2751. https://doi.org/10.1111/j.1540-6261.2006.01003.x

31. Sae-Lima, P., \& Jermsittiparsertb, K. (2019). Audit Committee and Earnings Quality. world, 6(2).

32. Saleem, F., Alifiah, M. N., \& Tahir, M. S. (2016). The effectiveness of monitoring mechanisms for constraining earnings management: A literature survey for a conceptual framework. International Journal of Economics and Financial Issues, 6(3S), 209-214.

33. Sirait, F., \& Siregar, S. V. (2014). Dividend payment and earnings quality: evidence from Indonesia. International Journal of Accounting and Information Management, 22(2), 103-127. https://doi.org/10.1108/IJAIM-04-2013-0034

34. Skinner, D. J., \& Soltes, E. (2011). What do dividends tell us about earnings quality? Review of Accounting Studies, 16(1), 1-28. https://doi.org/10.1007/s11142-009-9113-8

35. Tong, Y. H., \& Miao, B. (2011). Are dividends associated with the quality of earnings? Accounting horizons, 25(1), 183-205. https://doi.org/10.2308/acch.2011.25.1.183

36. Waweru, N. M., \& Prot, N. P. (2018). Corporate governance compliance and accrual earnings management in eastern Africa. Managerial Auditing Journal, 33(2), 171-191. https://doi.org/10.1108/MAJ-09-2016-1438

37. Wibowo, S. S. A. (2019). Effect of dividend payment on the earnings quality. Paper presented at the 1st International Conference on Applied Economics and Social Science (ICAESS 2019), Batam, Indonesia. https://doi.org/10.2991/icaess-19.2019.42

38. Younis, S. A., Hashmi, S. H., Khalid, G. K., \& Nazir, M. I. (2016). Impact of corporate governance measures on earnings quality: evidence from Pakistan. Research Journal of Finance and Accounting, 7(3), 9-16. 